\title{
Marie Väfors Fritz \& Ardavan Khoshnood (red.) Brottslighet och utsatthet $i$ Malmö
}

Studentlitteratur, 2019 (171 sider) ISBN 9789144126272

Der er en stærk tradition inden for sociologi, herunder ikke mindst kriminologi, for at studere et bestemt »bylivsfænomen« fra flere forskellige perspektiver, der (mindst) strækker sig helt tilbage til »den første Chicago Skole« i 1920-1930erne. Uden at være entydigt etnografisk, endsige sociologisk, skriver nærværende antologi om kriminalitet og udsathed i Malmö sig på sin egen måde ind i denne skole. Med denne bog tilbyder forfatterne, med deres egne ord, et øjebliksbillede eller et tværsnitsbillede, der ikke søger den fuldstændige beskrivelse af givne sociale fænomener, men som snarere maner til kritisk refleksion over andres og egne fordomme om Malmö, kriminalitet og udsathed.

Malmö er, som forfatteren tilmed gør klart i bogens forord, en by plaget af øget voldskriminalitet især i visse socialt udgrænsede boligområder. Det er i hvert fald dét billede, som medierne tegner. Imidlertid forholder det sig samtidig således, at Malmö figurerer på en europæisk top-10-liste over byer med de mest tilfredse (belåtna) medborgere. Malmö er Sveriges sydligst beliggende storby og fungerer på sin vis som en slags port til flere af Sveriges nabolande herunder især Tyskland, Polen og Danmark. I lyset af den demografiske og sociale kompleksitet, der følger heraf, kan Brottslighet och utsatthet $i$ Malmö vel forstås som et forsøg på at nuancere debatten om Malmös sociale og kriminalitetsmæssige udvikling igennem de seneste år. Det antydes af forfatterne i bogens allerførste sætninger:

»Denne bok beskriver en del av den utsatthet och brottslighet som har funnits i Malmö de senaste 15 åren, och som har gjort ett stort avtryk på staden, kanske för stort« (s. 11)

Bogens forfattere gør på denne måde glimrende opmærksom på, at det er både interessant og vigtigt at studere kriminaliteten og den sociale udsathed i Malmö videnskabeligt. Antologien fremstår særdeles motiveret.

Igennem kapitlerne brydes de to overordnede temaer, kriminalitet og udsathed, ned i en række delfænomener som f.eks. offer og gerningsmand, politi, vold med skydevåben og bomber, brandstiftelse og »hate-crime« samt misbrug, tiggeri, der tilsammen bidrager til at sagen belyses bredt og dybt, dog samtidig fokuseret. 
Bogen afsluttes med et kapitel skrevet af den erfarne forsker, psykiatriker og debattør Sten Levander, der synes at stå lidt »ved siden af « bogens øvrige bidrag. Kapitlet udgør en personlig beretning over udviklingen af nogle af de vigtigste kriminologiske behandlingsmodeller og kriminalitetsforebyggende indsatser i Sverige samt en kritisk diskussion heraf.

Bogen bringer ikke blot flere forskellige videnskabelige fagligheder i spil, så som både kvalitative og kvantitative undersøgelsesmåder samt både empiriske og teoretiske grundmotiver; også praktikerens perspektiv og kandidatstuderendes tanker inddrages. Analyserne og pointerne i f.eks. Brunner og Lengels (hhv. masterstudent og frivårdsinspektør) udmærkede identitetsteoretiske analyse af narkotikaafhængige kvinders kamp for stoffrihed synes ingenlunde mindre substantielle end de, der fremføres i de kapitler, der er skrevet af seniorforskere. Derimod tilføres bogen hermed en mangfoldighed, der dels afspejler den sag der studeres; dels betyder at bogen kan have interesse for andre end universitetsansatte kriminologer, herunder f.eks. psykologer, sociologer og forskere i socialt arbejde.

Det min opfattelse at bogen kan læses og anvendes af skandinaviske universitetsstuderende (samt lærerstuderende, sygeplejestuderende og ikke mindst socialrådgiverstuderende) med interesse for kriminalitet og udsathed - især i arbejdet med større skriftlige opgaver, som f.eks. bachelorprojektet eller kandidatspecialet.

\section{Asbjørn Storgaard,}

Ph.d.-studerende, Lunds universitet 